\title{
Pengaruh Motivasi Terhadap Kinerja Karyawan \\ Pada UPT Divisi IT, Infokom dan Pusdikom Universitas PGRI Palembang
}

\author{
Ermini \\ Pendidikan Matematika, FKIP Universitas PGRI Palembang, servaldae@gmail.com
}

\begin{abstract}
ABSTRAK
Rumusan masalah dalam penelitian ini adalah bagaimana pengaruh motivasi terhadap kinerja karyawan pada UPT Divisi IT, Infokom dan Pusdikom Universitas PGRI Palembang. Sedangkan tujuan penelitian ini untuk mengetahui apakah ada pengaruh motivasi terhadap kinerja karyawan pada UPT Divisi IT, Infokom dan Pusdikom Universitas PGRI Palembang. Teknik analisis yang digunakan dalam penelitian ini adalah regresi linier sederhana, analisis korelasi dan uji hipotesis t. Metode yang digunakan yaitu analisis kuantitatif. Hasil analisis yang diperoleh dengan menggunakan rumus regresi linier sederhana yaitu $y=7,02+0,88 X$. dengan analisis korelasi didapat nilai $r=0,63$. ini berarti terdapat pengaruh yang kuat antara motivasi terhadap kinerja karyawan pada UPT Divisi IT, Infokom dan Pusdikom Universitas PGRI Palembang, yaitu 39,69\%. Dan menolak hipotesis nol karena nilai thitung lebih besar dari $t$-tabel, yaitu 4,29 $>2,045$. Semakin tinggi motivasi maka kinerja yang dihasilkan akan meningkat. Dari hasil analisis ini dapat diambil kesimpulan bahwa motivasi mempunyai pengaruh yang kuat terhadap kinerja karyawan dan sebaiknya pimpinan dapat menerapkan pola kerja yang efektif sebagai bentuk motivasi agar kinerja karyawan itu sendiri dapat meningkat dan pada akhirnya tujuan organisasi dapat tercapai.
\end{abstract}

Kata Kunci : Motivasi dan Kinerja

\section{A. PENDAhUluan}

Dalam suatu organisasi, segala sesuatu yang dilakukan dituntut untuk dapat berjalan cepat, lancar, dan terarah dalam rangka penyesuaian dengan tindakan modernisasi yang terus berkembang serta mencapai tujuan secara efektif dan efisien. Untuk mencapai setiap tujuan yang telah ditetapkan oleh suatu organisasi dibutuhkan peranan sumber daya manusia yang mampu mengatur dan mengelola organisasi tersebut dengan baik dan profesional. Hal ini karena manusia merupakan perencana, pelaku, dan penentu dalam keberhasilan suatu organisasi dalam mencapai tujuan yang telah ditetapkan.

Menyadari betapa pentingnya peranan sumber daya manusia atau tenaga kerja di dalam organisasi, maka keberadaannya harus diperhatikan oleh para pimpinan di mana bentuk perhatiaannya dapat berupa kompensasi-kompensasi yang dapat berbentuk materi ataupun non materi dan cenderung di terima oleh organisasi, serta tidak hanya penting sebagai dorongan utama seseorang menjadi karyawan tetapi juga berpengaruh besar terhadap kinerja karyawan yang mana nantinya akan berpengaruh langsung terhadap tingkat produktivitas yang dihasilkan oleh organisasi secara keseluruhan.

Dewasa ini sebagian organisasi berkeinginan, hasil penilaian prestasi kerja dijadikan sebagai alat pendorong untuk memacu motivasi karyawan dalam melaksanakan pekerjaannya. Dengan upaya tersebut diharapkan selain meningkatkan produktivitas karyawan juga dapat meningkatkan rasa memiliki dan loyal kepada organisasi. Jika hal ini terjadi, maka dapat dikatakan, bahwa sumber daya manusia dalam suatu organisasi sudah dimanfaatkan secara efisien dan efektif. 
Setiap organisasi, baik itu organisasi swasta yang bersifat mencari keuntungan maupun organisasi atau instansi pemerintah yang umumnya melaksanakan kebijaksanaan publik. Begitu juga halnya dengan UPT Divisi IT, Infokom dan Pusdikom Universitas PGRI Palembang, motivasi sangat dibutuhkan guna untuk meningkatkan produktivitas kerja sehingga kinerja yang dihasilkan akan lebih baik.

UPT Divisi IT, Infokom dan

Pusdikom Universitas PGRI

Palembang merupakan bagian penting dalam dunia pendidikan karena mempunyai visi dan misi ingin mewujudkan pengembangan berbagai model program pendidikan nonformal informal dan peningkatkan mutu pendidikan dan tenaga kependidikan nonformal informal yang berkualitas serta melaksanakan pelayanan bantuan teknis bagi unit pelaksanaan teknis sekaligus pelayanan uji coba model. Jika semua itu tidak dapat dilaksanakan dengan baik,maka hal ini akan menghambat pelaksanaan program yang telah direncanakan yang pada akhirnya dapat mengganggu jalannya pendidikan. Untuk memperbaiki semua itu, tentunya dibutuhkan motivasi para karyawan, karena jika para karyawan memiliki motivasi yang tinggi maka akan berpengaruh terhadap kinerja para karyawannya sehingga dapat menghasilkan produktivitas kerja yang maksimal.

\section{B. RUMUSAN MASALAH}

Berdasarkan uraian latar belakang masalah tersebut, penulis merumuskan masalah dalam penelitian ini yaitu : Bagaimana pengaruh motivasi terhadap kinerja karyawan pada UPT Divisi IT, Infokom dan Pusdikom Universitas PGRI Palembang.

\section{LANDASAN TEORI}

$>$ Pengertian Motivasi.

Menurut Sunyoto (2015:323) motivasi adalah suatu proses dimana kebutuhan-kebutuhan mendorong seseorang untuk melakukan serangkaian kegiatan yang mengarah tercapainya tujuan tertentu.

Liang Gie dalam Samsudin (2009:281) motivasi adalah pekerjaan yang dilakukan oleh manejer dalam memberikan inspirasi, semangat, dan dorongan kepada orang lain, dalam hal ini karyawannya, untuk mengambil tindakan-tindakan tertentu.

$>\quad$ Tujuan Motivasi

Pemberian motivasi sangatlah penting karena dengan motivasi ini, diharapkan setiap individu karyawan mau bekerja keras dan antusias untuk mencapai kinerja karyawan yang tinggi. Menurut Hasibuan (2017:146) pemberian motivasi kepada karyawan bertujuan untuk :

1. Meningkatkan moral dan kepuasan kerja karyawan.

2. meningkatkan produktifitas kerja karyawan.

3. Mempertahankan kestabilan karyawan.

4. Meningkatkan kedisilplinan karyawan.

5. Mengefektifkan pengadaan kerja karyawan.

6. Menciptakan suasana dan hubungan kerja yang baik.

7. Meningkatkan loyalitas, kreativitas, dan partisipasi karyawan.

8. Meningkatkan tingkat kesejahteraan karyawan.

9. Mempertinggi rasa tanggung jawab karyawan terhadap tugastugasnya.

10. Meningkatkan efisiensi penggunaan alat-alat dan bahan baku. 
> Pengertian Kinerja Karyawan Menurut

Prawirosentono (2015:2), "Kinerja (performance) adalah hasil kerja yang dapat dicapai oleh seseorang atau kelompok orang dalam suatu organisasi sesuai dengan wewenang dan tanggung jawab masing-masing dalam rangka mencapai tujuan organisasi yang bersangkutan secara legal, tidak melanggar hukum dan sesuai dengan moral serta etika".

\section{METODE PENELITIAN}

$>$ Definisi Operasional

Motivasi adalah sesuatu yang pokok yang mendorong seseorang melakukan suatu tindakan-tindakan untuk mencapai tujuan yang telah ditetapkan. Sedangkan kinerja karyawan adalah hasil atau prestasi kerja yang diperoleh oleh seseorang karyawan atau sekelompok orang karyawan dalam suatu organisasi melalui kemampuan kerja yang dimilikinya.
Berdasarkan definisi operasional di atas, variabel dalam penelitian ini adalah sebagai berikut :

1. Variabel bebas (independen) yang disebut dengan variabel $X$, merupakan variabel yang tidak tergantung dengan variabel lainnya. Variabel $X$ dalam penelitian ini adalah motivasi.

2. Variabel terikat (Dependen) yang disebut dengan variabel $\mathrm{Y}$, merupakan variabel yang terantung atau terpengaruh oleh variabel lainnya. Variabel $Y$ dalam penelitian ini adalah kinerja karyawan.

\section{E. POPULASI DAN SAMPEL}

1) Populasi

"Populasi adalah keseluruhan objek penelitian" Arikunto (2012:108), adapun populasi dalam penelitian ini adalah semua karyawan yang ada pada UPT Divisi IT, Infokom dan Pusdikom Universitas PGRI Palembang yang berjumlah 30 orang. Untuk lebih jelasnya dapat dilihat pada tabel berikut ini :

TABEL 1

JUMLAH KARYAWAN

\begin{tabular}{|c|c|c|}
\hline No & Sub Bagian & Jumlah \\
\hline 1 & Pejabat Struktural & 6 \\
\hline 2 & Staf & 8 \\
\hline 3 & Tenaga Fungsional & 16 \\
\hline & Jumlah & 30 \\
\hline
\end{tabular}

Sumber : Data Primer (UPT Divisi IT, Infokom dan Pusdikom Universitas PGRI Palembang)

\section{2) Sampel}

Sampel adalah sebagian atau mewakili populasi penelitian (Arikunto,2012:109). Selanjutnya menurut Arikunto (2012:112), apabila subjek yang diteliti kurang dari 100 , lebih baik diambil semua sehingga penelitiaannya merupakan penelitian populasi, sedangkan jika jumlah subjeknya lebih dari 100 , maka diambil $10 \%-15 \%$ atau $20 \%-25 \%$ tergantung dari kemampuan peneliti yang dilihat dari segi waktu dan luasnya wilayah penelitian. Berdasarkan pendapat tersebut diatas, penulis mengambil keseluruhan populasi yang ada sebagai sempel dalam penelitian ini adalah sebanyak 15 orang.

\section{F. TEKNIK PENGUMPULAN DATA}

Teknik pengumpulan data yang digunakan penulis dalam penelitian ini adalah sebagai berikut : 
1. Observasi

Yaitu pengumpulan data dengan cara mengadakan pengamatan langsung keadaan yang ada pada suatu organisasi yang diteliti.

2. Wawancara

Wawancara merupakan instrumen pengumpulan data yang digunakan penulis untuk memperoleh informasi langsung dari sumbernya.

3. Studi Pustaka

Pengumpulan data yang bertujuan untuk memperoleh data sekunder dengan cara mengunjungi perpustakaan untuk mencari literatur yang berhubungan dengan masalah yang sedang diteliti.

4. Angket/Kuesioner

Memberikan beberapa pertanyaan secara tertulis kepada karyawan yang ada di UPT Divisi IT, Infokom dan Pusdikom Universitas PGRI Palembang dengan menggunakan kuesioner.

\section{G. TEKNIK ANALISIS DATA}

a. Analisis Kualitatif

Analisis yang tidak dapat dinyatakan dalam angka-angka dan bisa merupakan jawaban dari sebuah peristiwa yang sulit diukur.

b. Analisis Kuantitatif

Analisis yang dapat dinyatakan dalam angka-angka dan dapat dihitung dengan rumus statistik.

Teknik analisis data yang penulis gunakan yakni teknik analisis data kuantitatif, yaitu suatu metode analisis yang menggunakan perhitungan angka-angka untuk pengambilan keputusan. Dalam penelitian ini penulis menggunakan tiga macam teknik, yaitu analisis regresi linier sederhana, analisis koefisien korelasi, dan uji t.
Analisis

Regresi

Linier

Sederhana

Analisis regresi linier sederhana digunakan untuk mengetahui pengaruh antara dua variabel yang diteliti, yakni variabel motivasi terhadap variabel lainnya yaitu kinerja karyawan. Adapun rumus yang penulis gunakan adalah :

$\hat{Y}=a+b X$

(Riduwan, 2013:244)

Sedangkan untuk mencari nilai a dan $b$ digunakan rumus sebagai berikut :

$$
\begin{aligned}
& \mathrm{b}=\frac{n \cdot \sum X Y-\left(\sum X\right)\left(\sum Y\right)}{n \cdot \sum X^{2}-\left(\sum X\right)^{2}} \\
& \mathrm{a}=\frac{\sum Y-b \cdot \sum X}{n}
\end{aligned}
$$

Keterangan :

$$
\begin{array}{ll}
\mathrm{X} & =\text { Variabel bebas, motivasi } \\
\mathrm{Y} & =\text { Variabel terikat, kinerja karyawan } \\
\mathrm{a} & =\text { Konstanta } \\
\mathrm{b} & =\text { Koefisien regresi } \\
\mathrm{n} & =\text { Jumlah responden }
\end{array}
$$

$>\quad$ Analisis Koefisien Korelasi

Analisis koefisien korelasi digunakan untuk mengetahui hubungan antara variabel-variabel yang diteliti. Adapun rumus yang penulis gunakan adalah rumus Korelasi Product Moment berikut ini :

$$
r_{\mathrm{xy}}=\frac{n \cdot \sum X Y-\left(\sum X\right)\left(\sum Y\right)}{\sqrt{\left(n \cdot \sum X^{2}-\left(\sum X\right)^{2}\right)\left(n \cdot \sum Y^{2}-\left(\sum Y\right)^{2}\right)}}
$$

(Riduwan,2013:227)

Keterangan :

rxy $=$ Korelasi antara variabel $\mathrm{x}$ dan $\mathrm{y}$

$\mathrm{X} \quad=$ Variabel $\mathrm{x}$ (motivasi)

$\mathrm{Y} \quad=$ Variabel y (kinerja karyawan)

$\mathrm{n} \quad=$ Jumlah subjek

$\sum \quad=$ Jumlah keseluruhan

Menurut Riduwan (2013:228) untuk mengetahui tingkat hubungan antara variabel $X$ dengan variabel $Y$, dapat dilihat melalui tabel berikut ini : 
Tabel 2

Tingkat hubungan motivasi terhadap kinerja karyawan

\begin{tabular}{|c|c|}
\hline Interval koefisien & Tingkat hubungan \\
\hline $0,00-0,199$ & Sangat rendah \\
$0,20-0,399$ & Rendah \\
$0,40-0,599$ & Sedang \\
$0,60-0,799$ & Kuat \\
$0,80-1,000$ & Sangat kuat \\
\hline
\end{tabular}

Sumber : Riduwan Dalam Dasar-Dasar Statistika.

$>\quad U j i t$

Hipotesis penelitian yang akan digunakan adalah :

Ho = Tidak terdapat pengaruh antara motivasi dengan kinerja karyawan.

$\mathrm{Hi}=$ Terdapat pengaruh antara motivasi terhadap kinerja karyawan.

Pada tingkat keyakinan 95\%, dimana uji $t$ ini dilakukan untuk mengetahui ada tidaknya pengaruh yang signifikan antara kedua variable, maka digunakan rumus sebagai berikut:

$\mathrm{t}=\mathrm{r} \sqrt{\frac{n-2}{1-r^{2}}}$

(Riduwan, 2013:229)

Keterangan :

$r=$ Koefisien Korelasi

$\mathrm{n}=$ Banyaknya sampel yang diamati

Ho diterima Hi ditolak, apabila thitung $\leq t$ tabel. $\mathrm{Hi}$ ditolak Ho diterima, apabila thitung $\geq \mathrm{t}$ tabel.

\section{H. HASIL PENELITIAN DAN PEMBAHASAN}

$>$ Analisis Regresi Linier Sederhana.

Berdasarkan data diatas, penulis akan mencari pengaruh antara variabel $X$ dan variabel $Y$ dengan cara memasukan data tersebut kedalam rumus regresi linier sederhana sehingga di dapatkan hasil sebagai berikut :

$\hat{Y}=a+b X$

Keterangan :

$$
\begin{aligned}
\hat{Y} & =\text { Kinerja Karyawan } \\
X & =\text { Motivasi } \\
\mathrm{a} & =\text { Konstanta } \\
\mathrm{b} & =\text { Koefisien regresi. }
\end{aligned}
$$

Dimana :

$$
\begin{aligned}
\mathrm{b} & =\frac{n \sum X Y-\left(\sum X\right)\left(\sum Y\right)}{n \sum X^{2}-\left(\sum X\right)^{2}} \\
& =\frac{30 \cdot(56416)-(1272)(1330)}{30 \cdot(53960)-(1272)^{2}} \\
& =\frac{1692480-1691760}{1618800-1617984} \\
& =\frac{720}{816}=0,882352941=0,88 \\
\mathrm{a} & =\frac{\sum Y-b \cdot \sum X}{n} \\
& =\frac{(1330)-(0,88)(1272)}{30} \\
& =\frac{(1330)-(1119,36)}{30} \\
& =\frac{210,64}{30}=7,0213333=7,02
\end{aligned}
$$

Berdasarkan perhitungan diatas, hasil a didapat dengan nilai 7,02 dan hasil b didapat dengan nilai 0,88 . sehingga pengaruh motivasi terhadap kinerja karyawan dengan menggunakan rumus persamaan regresi linier sederhana adalah :

$\hat{Y}=7,02+0,88 X$.

Analisis Koefisien Korelasi Product Moment.

Setelah diketahui bahwa terdapat pengaruh antara motivasi dengan 
kinerja karyawan, ini berarti terdapat pula hubungan antara variabel-variabel tersebut. Untuk memperkuat hasil pengaruh yang telah diketahui tadi dapat dilakukan dengan melihat kuat tidaknya hubungan antara variabel motivasi dan kinerja karyawan. Kuat tidaknya hubungan antara dua variabel tersebut dapat dicari dengan menggunakan rumus koefisien korelasi product moment seperti berikut ini :

$$
\begin{aligned}
& r_{x y}=\frac{n \cdot \sum X Y-\left(\sum X\right)\left(\sum Y\right)}{\sqrt{\left(n \cdot \sum X^{2}-\left(\sum X\right)^{2}\right)\left(n \cdot \sum Y^{2}-\left(\sum Y\right)^{2}\right)}} \\
& =\frac{30 .(56416)-(1272)(1330)}{\sqrt{\left(30.53960-(1272)^{2}\right) \sqrt{\left(30.59016-(1330)^{2}\right)}}} \\
& =\frac{1692480-1691760}{\sqrt{(1618800-1617984)(1770480-1768900)}} \\
& =\frac{720}{\sqrt{(816)(1580)}}=\frac{720}{\sqrt{1289280}} \\
& =\frac{720}{1135,464663}=0,634101635=0,63 .
\end{aligned}
$$

Dari hasil perhitungan yang ada diatas tadi dapat diketahui bahwa terdapat hubungan sebesar 0,63 antara variabel $\mathrm{X}$ dengan Variabel $\mathrm{Y}$.

Selanjutnya penulis akan mencari seberapa besar persentase pengaruh motivasi terhadap kinerja karyawan UPT Divisi IT, Infokom dan Pusdikom Universitas PGRI Palembang dengan cara menghitung koefisien determinasi koefisien penentu sehingga didapatkan hasil sebagai berikut :

$$
\begin{aligned}
\mathrm{KP} & =r^{2} \cdot 100 \% \\
& =(0,63)^{2} \cdot 100 \% \\
& =0,3969 \cdot 100 \%=39,69 \%
\end{aligned}
$$

Dari perhitungan koefisien determinasi diatas, didapatkan hasil sebesar 0,3969 atau 3969\%. Hal ini dapat diartikan bahwa kekuatan motivasi untuk mempengaruhi kinerja karyawan hanya sebesar $39,69 \%$ dan sisanya yaitu $60,31 \%$ dipengaruhi oleh faktor-faktor lain.

\section{$>\quad$ Pengujian Hipotesis}

Langkah-langkah dalam pengujian hipotesis sebagai berikut :

a. Menyusun formulasi $\mathrm{Ho}$ dan $\mathrm{Hi}$

Berdasarkan hipotesis yang sudah dikemukakan sebelumnya, bahwa terdapat pengaruh motivasi terhadap kinerja karyawan pada UPT Divisi IT, Infokom dan Pusdikom Universitas PGRI Palembang. Dari hipotesis tersebut akan diformulasikan hipotesis nol (Ho) dan hipotesis alternative $(\mathrm{Hi})$ sebagai berikut :

Ho: Tidak terdapat pengaruh antara motivasi terhadap kinerja karyawan.

$\mathrm{Hi}$ : Terdapat pengaruh antara motivasi terhadap kinerja karyawan.

b. Menentukan alphanya

Tingkat kepercayaan yang digunakan adalah $95 \%$, ini berarti nilai alphanya adalah $5 \%$.

$n-2=30-2=28$

$\mathrm{t}_{\text {-tabel }}=\frac{\alpha}{2}=\frac{0,05}{2}=0,025$

Jika alphanya 0,025 , maka akan menerima hipotesis nol jika $t$ terletak diantara -2,045 dan 2,045 (Lihat tabel nilai tabel terlampir)

c. Kriteria Pengujian

Ho ditolak apabila t-hitung lebih besar dari t-tabel dan sebaliknya, Ho diterima apabila t-hitung lebih kecil dari $t_{\text {-tabel. }}$ Ho ditolak berarti variabel $X$ berpengaruh terhadap variabel $Y$, tetapi jika Ho diterima, ini berarti variabel $X$ (motivasi) tidak berpengaruh terhadap variabel $Y$ (kinerja karyawan).

d. Perhitungan nilai t.

Perhitungan nilai $t$, menggunakan rumus sebagai berikut : 


$$
\mathrm{t}=\mathrm{r} \sqrt{\frac{n-2}{1-r^{2}}}
$$

Perhitungannya :

$$
\begin{aligned}
& t=0,63 \sqrt{\frac{30-2}{1-(0,63)^{2}}}=0,63 \sqrt{\frac{28}{1-0,3969}} \\
& t=0,63 \sqrt{\frac{28}{0,6031}}=0,63 \sqrt{46,43} \\
& t=0,63(6,81) t=4,29 .
\end{aligned}
$$

e. Ho diterima atau Tidak (Kesimpulan)

Berdasarkan perhitungan nilai $\mathrm{t}$ diatas, dapat diketahui bahwa nilai t-hitung adalah 4,29, sedangkan $t$-tabel diketahui 2,045. karena $t_{\text {-hitung }}$ lebih besar dari $\mathrm{t}_{-}$ tabel $\quad(4,29>2,045), \quad$ maka keputusannya adalah menolak hipotesis nol (Ho). Ho ditolak berarti ada pengaruh yang cukup signifikan antara variabel $X$ (motivasi) dan variabel $Y$ (kinerja karyawan). Jadi, dapat disimpulkan bahwa secara statistik, motivasi mempunyai pengaruh yang cukup signifikan terhadap kinerja karyawan.

Dari penjelasan diatas, maka dapat disimpulkan bahwa hipotesis yang dibuat penulis dalam bab I telah teruji, dimana motivasi mempunyai pengaruh yang cukup signifikan terhadap kinerja karyawan. Jadi, semakin besar motivasi yang dimiliki seorang karyawan maka kinerja yang dihasilkannya akan semakin meningkat.

\section{> Bentuk Motivasi Yang Dapat Meningkatkan Kinerja Karyawan \\ Untuk menganalisis perumusan} masalah yang kedua, maka penulis menggunakan metode persentase untuk mencari motivasi yang paling diminati oleh karyawan pada UPT Divisi IT, Infokom dan Pusdikom Universitas PGRI Palembang. Usaha yang dilakukan pimpinan dalam memotivasi karyawan agar tercapai kinerja karyawan dapat dilakukan dengan mengatahui bentuk motivasi yang paling diinginkan oleh karyawan tersebut.

Berikut ini tanggapan responden dalam hal ini adalah karyawan UPT Divisi IT, Infokom dan Pusdikom Universitas PGRI Palembang tentang bentuk motivasi yang diminati dalam upaya meningkatkan kinerja karyawan.

Tabel 3

Tanggapan responden tentang bentuk motivasi yang diminati

\begin{tabular}{|c|c|c|c|}
\hline No. & Bentuk motivasi & Jumlah responden & Persentase \\
\hline 1. & Kompensasi dalam bentuk uang & - & - \\
2. & Pengarahan dan pengendalian & 8 & $27 \%$ \\
3. & Pola kerja yang efektif & 20 & $66 \%$ \\
4. & Kebajikan & 2 & $7 \%$ \\
\hline & Jumlah total & 30 & $100 \%$ \\
\hline
\end{tabular}

Sumber : Karyawan UPT Divisi IT, Infokom dan Pusdikom Universitas PGRI Palembang.

Dari hasil perolehan data diatas, dapat dilihat bahwa responden yang memilih pola kerja yang efektif berjumlah 20 karyawan (66\%), pengarahan dan pengendalian dipilih oleh 8 karyawan $(27 \%)$, sedangkan kebajikan hanya dipilh oleh 2 karyawan (7\%). Dengan demikian, dapat diketahui bahwa bentuk motivasi yang paling diminati oleh karyawan UPT Divisi IT, Infokom dan Pusdikom Universitas PGRI Palembang guna 
meningkatkan kinerja karyawan bisa dilihat dari tabel diatas adalah pola kerja efektif dimana ada 20 dari 30 karyawan telah memilih bentuk motivasi tersebut.

Memotivasi karyawan untuk meningkatkan potensi dan keahlian guna mencapai tujuan organisasi merupakan suatu hal yang harus dilakukan oleh seorang pimpinan. Apabila karyawan telah termotivasi dalam melakukan tugas dan tanggung jawabnya, maka karyawan tersebut akan mencoba dengan semaksimal mungkin agar upaya tersebut dapat menghasilkan kinerja karyawan yang baik yang akhirnya berujung pada tercapainya tujuan organisasi/instansi. Motivasi juga dapat mendorong karyawan agar dapat bekerja keras untuk merealisasikan tujuan serta mengaplikasikan kemampuan dan keahlian yang dimiliki untuk mencapai tujuan tersebut. Hal ini dapat diartikan bahwa motivasi mempunyai pengaruh terhadap kinerja karyawan.

Pengaruh motivasi tehadap kinerja karyawan juga dapat dibuktikan dengan menggunakan rumus regresi linier sederhana. Dari hasil persamaan regresi linier sederhana yang telah diketahui tadi, maka dapat digunakan untuk melihat pengaruh dan melakukan peramalan terhadap nilai kinerja karyawan apabila nilai motivasi dinaikkan atau diturunkan.

Misalkan nilai $X=15$ dan 17 ,

Bila $X=15$, maka

$\hat{Y}=7,02+0,88 X$.

$\hat{Y}=7,02+0,88(15)$

$\hat{Y}=20,22$

Bila $X=17$, maka

$\hat{Y}=7,02+0,88 X$.

$\hat{Y}=7,02+0,88(17)$

$\hat{Y}=21,98$
Ini berarti pengaruh antara motivasi terhadap kinerja karyawan dapat diketahui dengan melihat kenaikan nilai $X$ yang diikuti pula dengan kenaikan nilai $Y$, yang artinya jika motivasi meningkat maka kinerja karyawan akan meningkat.

Sedangkan mencari kuat tidaknya suatu hubungan antara motivasi dengan kinerja karyawan yang telah didapat dengan menggunakan rumus koefisien korelasi product moment, maka karena hasil yang didapat merupakan angka positif, hal ini berarti memang benar motivasi mempunyai hubungan terhadap kinerja karyawan. Berdasarkan hasil perhitungan koefisien korelasi product moment antara variabel motivasi dengan variabel kinerja karyawan yaitu 0,63 , jika dilihat dari tabel 2 maka hasil tersebut masuk kedalam kategori kuat yaitu antara 0,60 sampai dengan 0,799 .

Akan tetapi motivasi bukanlah satu-satunya faktor yang mempengaruhi kinerja karyawan. Setelah diketahui seberapa kuat motivasi dalam mempengaruhi kinerja karyawan jika dilihat dari hasil yang diperoleh melalui rumus koefisien determinasi tadi, maka ini membuktikan bahwa faktor-faktor yang lain juga sangat besar pengarunya melebihi faktor motivasi terhadap kinerja karyawan UPT Divisi IT, Infokom dan Pusdikom Universitas PGRI Palembang. Menurut William Stern dalam Mangkunegara (2013:16) terdapat dua faktor yang mempengaruhi kinerja seorang karyawan, yaitu sebagai berikut :

1. Faktor Individu.

Secara psikologis, individu yang normal adalah individu yang memiliki integritas yang tinggi antara fungsi psikis (rohani) dan fisiknya (jasmaniah). Dengan adanya integritas yang tinggi antara fungsi psikis dan 
fisik, maka individu tersebut memiliki konsentrasi diri yang baik. Konsentrasi yang baik ini merupakan modal utama individu manusia untuk mengelola dan mendayagunakan potensi dirinya secara optimal dalam melaksanakan kegiatan atau aktivitas kerja sehari-hari dalam mencapai tujuan organisasi.

Dengan kata lain, tanpa adanya konsentrasi yang baik dari individu dalam bekerja, maka mimpi pimpinan mengharapkan mereka dapat bekerja produktif dalam mencapai tujuan organisasi. Konsentrasi individu dalam bekerja sangat dipengaruhi oleh kemampuan potensi, yaitu kecerdasan pikiran / Inteligensi Quotiont (IQ) dan kecerdasan emosi/Emotional Quotiont (EQ). Pada umumnya, individu yang mampu bekerja dengan penuh konsentrasi apabila ia memiliki tingkat inteligensi minimal normal (average, above average, superior, very superior dan gifted) dengan tingkat kecerdasan emosi baik (tidak merasa bersalah yang berlebihan, tidak mudah marah, tidak dengki, tidak benci, tidak iri hati, tidak sombong, tidak cemas, memiliki pandangan dan pedoman hidup yang jelasberdasarkan kitab sucinya).

2. Faktor Lingkungan Organisasi. Faktor lingkungan kerja organisasi sangat menunjang bagi individu dalam mencapai prestasi kerja. Faktor lingkungan organisasi yang dimaksud antara lain uraian jabatan yang jelas, autoritas yang memadai, target kerja yang menantang, pola komunikasi kerja efektif, hubungan kerja harmonis, iklim kerja respek dan dinamis, preluang berkarir dan fasilitas kerja yang relatif memadai. Sekalipun, jika faktor organisasi kurang menunjang, maka bagi individu yang memiliki tingkat kecerdasan pikiran memadai dengan tingkat kecerdasan emosi baik, sebenarnya ia tetap dapat berprestasi dalam bekerja. Hal ini bagi individu tersebut, lingkungan organisasi tersebut dapat diubah dan bahkan diciptakan oleh dirinya serta merupakan pemacu (Pemotivator), tantangan bagi dirinya dalam berprestasi di organisasinya.

Kedua faktor tersebut saling berhubungan satu sama lain sehingga bila salah satu faktor tersebut rendah, maka tingkat kinerja karyawan juga akan rendah walaupun faktor-faktor lain yang mempengaruhi tinggi. Hal ini terjadi karena bila kemampuan karyawan dalam bekerja tinggi dan persepsi yang ditimbulkan oleh karyawan tersebut terhadap pekerjaannya baik akan tetapi motivasi yang ada baik didalam maupun diluar diri karyawan itu sendiri terhadap pekerjaannya rendah maka akan berdampak pada pelaksanan pekerjaan kurang maksimal karena karyawan tersebut tidak mempunyai semangat dan dorongan sehingga membuat malas untuk bekerja. Begitupun sebaliknya, jika motivasi yang ada didalam maupun diluar diri karyawan tinggi tetapi tidak diimbangi dengan kemampuan dalam bekerja yang tinggi pula maka akan membuat pekerjaan yang dijalani tidak efektif dikarenakan keahlian karyawan tersebut berkurang.

Setelah dietahui motivasi dapat mempengaruhi kinerja karyawan, maka dapat diketahui pula bentuk motivasi yang dapat meningkatkan kinerja seorang karyawan. Dari empat macam bentuk motivasi yang umum diterapkan oleh suatu organisasi / instansi termasuk juga pada UPT Divisi IT, Infokom dan Pusdikom Universitas PGRI Palembang, dalam hal ini penerapan pengarahan dan pengendalian, kebajikan, serta pemberian kompensasi dalam bentuk uang yang dilakukan pimpinan dirasa sudah terpenuhi sehingga sebagian 
besar karyawan UPT Divisi IT, Infokom dan Pusdikom Universitas PGRI Palembang lebih memilih pola kerja yang efektif yang dapat memotivasi karyawan tersebut untuk mencapai kinerja yang lebih baik.

Menurut Siswanto (2007:126) pola kerja yang efektif dapat diberikan dengan cara sebagai berikut :

1. Pengayaan pekerjaan

Pengayaan

pekerjaan maksudnya adalah menyesuaikan tuntutan pekerjaan yang dibebankan kepada karyawan dengan kemampuan karyawan itu sendiri. Kemampuan karyawan untuk menguasai suatu pekerjaan itu juga terbatas. Keterbatasan itu dapat berupa kurangnya fasilitas terhadap bidang pekerjaan yang sedang dijalani dan kehlian yang dirasa masih kurang cukup untuk menangani suatu pekerjaan yang sesuai dengan kemampuan dari karyawan itu sendiri pada akhirnya akan dapat meningkatkan kinerja yang baik sehingga tujuan serta visi dan misi organisasi tercapai.

2. Manajemen Partisipatif

Manajemen

partisipatif

maksudnya adalah menggunakan berbagai cara untuk melibatkan karyawan dalam pengambilan keputusan/decision making yang mempengaruhi pekerjaan karyawan itu sendiri. Seorang karyawan juga memiliki gagasan-gagasan yang kreatif dalam memecahkan persoalan yang dihadapi perusahaan. Oleh karena itu pimpinan juga harus memberikan kesempatan kepada para karyawan untuk dapat terlibat dalam pengambilan keputusan.

Pimpinan UPT Divisi IT, Infokom dan Pusdikom Universitas PGRI Palembang dalam memberikan pola kerja yang efektif harus sesuai dengan kemampuan dan keahlian yang dimiliki oleh karyawan itu sendiri. Ini dimaksudkan agar pekerjaan yang dijalani oleh karyawan tersebut terlaksana dengan baik.

\section{Kesimpulan dan Saran}

1) Kesimpulan

Dari hasil analisis data yang telah dilakukan dapat ditarik kesimpulan sebagai berikut :

a. Berdasarkan hasil perhitungan regresi linier sederhana dan koefisien korelasi product moment dengan menggunakan motivasi sebagai variabel $X$ dan kinerja karyawan sebagai variabel $Y$, maka diketahui bahwa terdapat pengaruh dari hubungan antara motivasi dengan kinerja karyawan. Persamaan regresi linier sederhana yang telah diketahui tadi, dapat digunakan untuk melakukan peramalan terhadap perubahan nilai kinerja karyawan apabila nilai motivasi dinaikkan atau diturunkan. Sedangkan hasil perhitungan koefisien korelasi product moment dapat dijadikan ukuran kuat-tidaknya hubungan motivasi terhadap kinerja karyawan UPT Divisi IT, Infokom dan Pusdikom Universitas PGRI Palembang.

b. Bentuk motivasi yang paling diminati oleh karyawan UPT Divisi IT, Infokom dan Pusdikom Universitas PGRI Palembang guna meningkatkan kinerja karyawan adalah pola kerja yang efektif dimana penerapan pengarahan dan pengendalian dan kebajikan serta pemberian kompensasi dalam bentuk uang yang dilakukan pimpinan dirasa sudah terpenuhi bagi sebagian besar karyawan.

c. Dari hasil pengujian hipotesis dengan memakai rumus uji t yang dilakukan penulis dengan cara membandingkan hasil dari 
koefisien korelasi product moment ( $r_{\text {hitung }}$ ) yaitu 4,29 dengan $r_{\text {tabel }}$ dengan tingkat kepercayaan 95\% untuk taraf kesalahan (@) $5 \%$ yaitu 2,045 diketahui bahwa $r_{\text {hitung lebih besar dari } r_{\text {tabel }}}$ $(4,29>2,045)$. Dengan demikian dapat disimpulkan bahwa jawaban dari hipotesis tersebut yaitu terdapat pengaruh motivasi terhadap kinerja karyawan dapat diterima.

2) Saran.

Berdasarkan hasil kesimpulan diatas, maka penulis memberikan saran sebagai berikut :

a. Pimpinan UPT Divisi IT, Infokom dan Pusdikom Universitas PGRI Palembang sebaiknya dapat meningkatkan kemampuan karyawan dalam penguasaan bidang pekerjaan, misalnya dengan memberikan pelatihan, pengembangan, serta pengarahan yang baik. Ini dilakukan agar kinerja karyawan tersebut dapat tercapai.

b. Sebaiknya pimpinan UPT Divisi IT, Infokom dan Pusdikom Universitas PGRI Palembang juga menerapkan pola kerja yang efektif sebagai bentuk motivasi agar kinerja karyawan itu sendiri dapat meningkat dan pada akhirnya tujuan organisasi dapat tercapai.

\section{DAFTAR PUSTAKA}

Arikunto, Suharsimi. 2013. Prosedur Penelitian Suatu Pendekatan Praktek. Edisi Revisi. Jakarta; Rineka Cipta

\section{Hasibuan, SP Malayu. (2017). Manajemen Sumber Daya Manusia (Edisi Revisi). Jakarta, Indonesia: Bumi Aksara.}

Prawirosentono, Suyadi., \& Primasari, Dewi. (2015). Manajemen Sumberdaya Manusia Kinerja \& Motivasi Karyawan, Membangun Organisasi Kompetitif Era Perdagangan Bebas Dunia (Edisi Ketiga). Yogyakarta, Indonesia: BPFE-Yogyakarta.

Mangkunegara (2013). Manajemen Sumber Daya Manusia Perusahaan. Cetakan ke-11. Bandung: Remaja Rosdakarya.

Riduan. 2013. Dasar-Dasar Statistika, Edisi Revisi. Bandung: Alfabeta.

Sunyoto, Danang. (2015). Penelitian Sumber Daya Manusia. Jakarta, Indonesia: CAPS (Center of Academic Publishing Service).

Samsudin, Sadili, 2009, Manajemen Sumber Daya Manusia, Pustaka Setia, Jakarta

$\begin{array}{ccc}\text { Siswanto. } & \text { (2007). } & \text { Pengantar } \\ \text { Manajemen. } & \text { (cet.3). } & \text { Jakarta, } \\ \text { Indonesia: } & \text { Bumi } & \text { Aksara. }\end{array}$

